\title{
Standardization of pulmonary ventilation technique using volume- controlled ventilators in rats with congenital diaphragmatic hernia
}

\author{
Padronização da técnica de ventilação pulmonar utilizando ventiladores com \\ volume controlado em ratos com hérnia diafragmática congênita
}

Rodrigo Melo Gallindo; Frances Lilian Lanhellas Gonçalves; Rebeca lopes Figueira; Ana Leda Bertoncini Simões; Lourenço Sbragia

\begin{abstract}
A B S T R A C T
Objective: To standardize a technique for ventilating rat fetuses with Congenital Diaphragmatic Hernia (CDH) using a volumecontrolled ventilator. Methods: Pregnant rats were divided into the following groups: a) control (C); b) exposed to nitrofen with $\mathrm{CDH}(\mathrm{CDH})$; and $\mathrm{c}$ ) exposed to nitrofen without $\mathrm{CDH}(\mathrm{N}-)$. Fetuses of the three groups were randomly divided into the subgroups ventilated $(\mathrm{V})$ and non-ventilated $(\mathrm{N}-\mathrm{V})$. Fetuses were collected on day 21.5 of gestation, weighed and ventilated for 30 minutes using a volume-controlled ventilator. Then the lungs were collected for histological study. We evaluated: body weight (BW), total lung weight (TLW), left lung weight (LLW), ratios TLW / BW and LLW / BW, morphological histology of the airways and causes of failures of ventilation. Results: BW, TLW, LLW, TLW / BW and LLW / BW were higher in C compared with N- $(p<0.05)$ and CDH $(p<0.05)$, but no differences were found between the subgroups $V$ and $N-V(p>0.05)$. The morphology of the pulmonary airways showed hypoplasia in groups $\mathrm{N}$ - and $\mathrm{CDH}$, with no difference between $\mathrm{V}$ and $\mathrm{N}-\mathrm{V}(\mathrm{p}<0.05)$. The $\mathrm{C}$ and $\mathrm{N}$ - groups could be successfully ventilated using a tidal volume of $75 \mathrm{il}$, but the failure of ventilation in the CDH group decreased only when ventilated with 50 il. Conclusion: Volume ventilation is possible in rats with CDH for a short period and does not alter fetal or lung morphology.
\end{abstract}

Key words: Hernia, diaphragmatic/congenital. Ventilation. Models, animal. Rats. Nitrophenols.

\section{INTRODUCTION}

C ongenital diaphragmatic hernia $(C D H)$ is a rare defect that affects about 1:2000 to 1:4000 of newborns ${ }^{1-3}$. Hypoplasia and pulmonary hypertension lead to respiratory distress and are primarily responsible for post-natal death 2. Mortality used to be $50 \%$ in patients with isolated $\mathrm{CDH}$, and around $80 \%$ with associated anomalies ${ }^{4-7}$, but in some centers it has been dropping to $20-30 \%$ with the introduction of standardized treatment protocols 1,3 .

Due to hypoplasia and pulmonary hypertension, patients with CDH have a difficult ventilatory handling, with right to left shunt, hypoxia, hypercapnia, and mixed acidosis. Thus, the frequency of lung injury, barotrauma and pneumothorax in these patients were very high, which most often caused death ${ }^{7}$. Wung et al. established the parameters currently used in assisted mechanical ventilation with low pressure and permissive hypercapnia (a gentle ventilation), and even delaying surgical correction ${ }^{8}$.

To study the $\mathrm{CDH}$, there are congenital, surgical or toxicological models ${ }^{9}$. The most studied model is the rat toxicological one through nitrofen (2,4-dichlorophenyl 4nitrophenyl ether). The nitrofen, which is a teratogen when administered at gestational day (GD) 9.5 leads to $C D H$ in about $40 \%$ of fetuses ${ }^{10}$, and the vast majority of the experimental studies in this model evaluates the lung at the end of gestation. Thus, it is not possible to evaluate the morphological and biochemical changes that occur after pulmonary ventilation.

Several models of ventilation in larger animals have been described in $\mathrm{CDH}$, such as in sheep ${ }^{11-13}$ and rabbits 14,15 , but these species lack options for conducting molecular studies. Due to the difficulty of lung ventilation in these patients, only one model has been described in small animals. Sluiter et al. ${ }^{14}$ adapted a model of ventilation for preterm rabbits to neonates of rats. Beyond this, only three more other studies ${ }^{15-17}$ have reproduced this model, probably due to technical difficulties, such as the use of an adapted sophisticated ventilator, and instruments to confirm that the ventilation is actually occurring.

Due to high neonatal mortality resulting from pulmonary hypoplasia and complications of ventilation

Discipline of Pediatric Surgery, Department of Surgery and Anatomy, Faculdade de Medicina de Ribeirão Preto, Universidade de São Paulo - USP, Ribeirão Preto, São Paulo - SP, Brazil. 
resulting from this defect, our goal was to standardize a more easily reproducible model of ventilation in rat fetuses with $\mathrm{CDH}$, using a volume-cycled ventilator, and to evaluate the changes caused in the parenchymal lung after ventilation.

\section{METHODS}

The study was approved by the Committee of Ethics in Animal Experimentation of the Faculty of Medicine of Ribeirão Preto of (CETEA), University of São Paulo (FMRPUSP), under number 043/2011.

Female Sprague-Dawley rats weighing around $250 \mathrm{~g}$ were subjected to overnight mating. The next day we performed a vaginal smear and, when watching a smear sperm, confirmed mating. This day was considered the day zero of the gestation (term $=22$ days). The animals were kept in cages with water and food ad libtum, under controlled conditions of lighting (12-hour lightness/12-hour darkness), temperature (average $23^{\circ} \mathrm{C}$ ) and relative air humidity (average 55\%).

We divided the pregnant rats into two groups: Control (C) and nitrofen (N). The rats of group $\mathrm{C}$ were not manipulated. The rats of group $\mathrm{N}$ were exposed to $100 \mathrm{mg}$ of nitrofen, diluted in $1 \mathrm{ml}$ of olive oil, on GD 9.5 according to Kluth et al. ${ }^{10}$. Fetuses exposed to nitrofen who developed $\mathrm{CDH}$ formed the $\mathrm{CDH}$ group, and those who did not develop CHD formed the group $\mathrm{N}$-. We divided the groups into ventilated (CV, N-V and CDHV) and unventilated (C, Nand $(\mathrm{CH})$.

On GD 21.5 the pregnant rats were anesthetized with an intramuscular injection of ketamine $(50 \mathrm{mg} / \mathrm{ml})$ associated with xylazine $(20 \mathrm{mg} / \mathrm{ml})$. We placed the anesthetized rats on a heated stage with a temperature of $37^{\circ} \mathrm{C}$. After disinfection with aqueous chlorhexidine, rats underwent laparotomy with exposure of fetal horns.

We collected the fetuses individually in the craniocaudal direction, starting from the right horn. The uterus was clamped with a Halstead clamp to prevent the next fetus to be expelled and returned to the abdominal cavity, which was covered with a sterile gauze soaked in saline. When necessary, a further $0.1 \mathrm{ml}$ dose of ketamine was administered intraperitoneally.

The fetus was weighed (body weight - BW), put under another heating stage at $37^{\circ} \mathrm{C}$ and fixed with tape in the supine position (Figure 1A); we then carried out a longitudinal neck incision, tracheal dissection (Figures 1B and $C$ ) tracheal section on its anterior aspect and insertion of a $24 \mathrm{G}$ Vialon $®$ catheter (Figure 1D). The catheter was connected to the end of an intravenous line for better connection to the ventilator. This set was connected to a volumecontrolled, timecycled ventilator (MiniVent type 845, Harvard Apparatus $($ ) (Figure $1 \mathrm{E})$, with a frequency of 80 cycles / min, $\mathrm{FiO}_{2}$ 1.0, l: E ratio of 1:1, PEEP $0 \mathrm{cmH}_{2} \mathrm{O}$ for 30 minutes. To prevent extubation, the connections between the ventilator and the tracheotomy catheter were fixed to the thermal table with modeling clay. After the end of
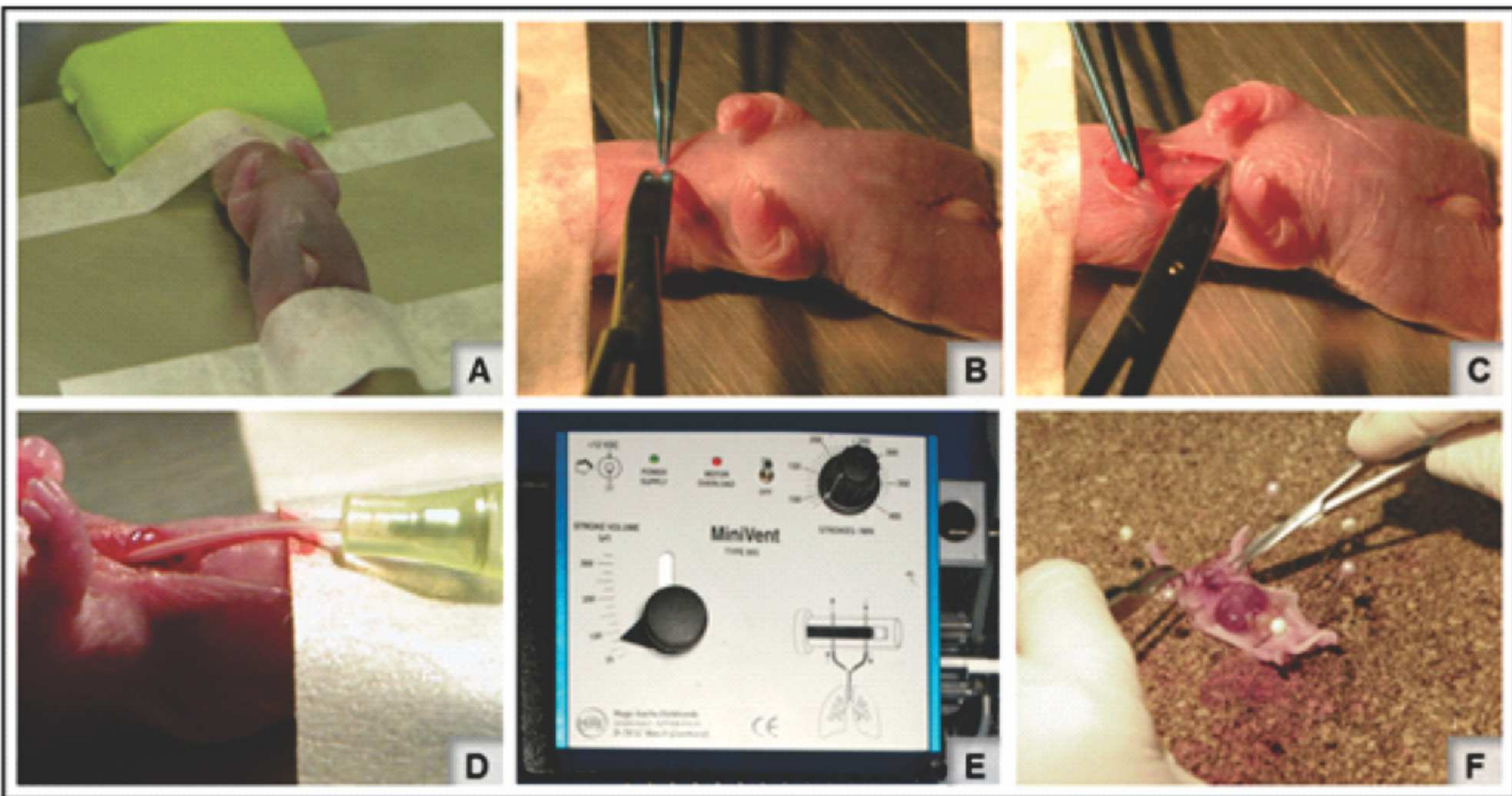

Figure 1

A) fetus positioned in supine on heated table (on average $38^{\circ} \mathrm{C}$ ) and fixed with adhesive tape; B) anterior cervical incision; C) isolation of the trachea followed by section; D) intubation with teflon catheter and ventilation; E) ventilator set at 80/min frequency and 75il volume; F) sacrifice by decapitation and positioning on of cork table for specimen collection. 
ventilation in ventilated fetuses, or after the body weighing in unventilated fetuses, they were sacrificed by decapitation and their lungs were dissected (Figure 1F) and harvested for lung weighing (total lung weight - TLW, and left lung weight - LLW) and sent for histological processing.

Calculated a tidal volume of approximately 13.5 $\mathrm{ml} / \mathrm{kg}$ in C fetuses (75il). Thia was greater than the volume used by Kroon et al. ${ }^{18}$, but with a lower frequency of cycling (80). $\mathrm{N}$ - fetuses and $\mathrm{CDH}$ were ventilated with decreasing volumes: 75, 63, 50 and $30 \mathrm{il}$, the failure rates being noted, defined by: pneumothorax (PT), pneumomediastinum (PM), identified by the air leakage around the trachea and failed tracheal catheterization (FTC), and success defined by observation of chest expansion and pink coloration of the fetus. Success rates and complications were constantly analyzed to find the optimum volume.

The following variables were measured: BW, TLW and LLW. To remove the influence of BW on the TLW and LLW, we calculated the TLW / BW and LLW / BW ratios. For fetal morphometric analysis, eight fetuses were collected from each subgroup after standardization of the current volume.

The samples were fixed in formaldehyde, dehydrated in alcohol, cleared in xylene and embedded in histology paraffin. Histological sections were made with a thickness of $5 \mathrm{im}$ and later collected in pre-silanized histological slides. The sections were stained with Masson's trichrome, and the slides were mounted in Permount ${ }^{\circledR}$.
Histological sections were photographed at 100x magnification in light microscope and the images were analyzed to obtain the mean linear intercept (Lm) and its components, internal diameter of the airspaces (Lma) and the mean wall transection length ( $(\mathrm{mW}$ ) according to the methods described by Dunhill ${ }^{19}$ and modified by Verbeken et al. ${ }^{20}$. Lung morphometric analysis was performed using six sections per fetus and four fetuses per subgroup.

Values obtained through weighting and measurements of lung parenchyma were analyzed by ANOVA with Tukey-Kramer post-test and expressed as mean \pm standard deviation. Differences were considered significant at $p<0.05$.

\section{RESULTS}

table 1.

Data on ventilation failures are grouped in

We found that the best volume to ventilate was $50 \mu \mathrm{l}$, with $53 \%$ success. Ventilation was possible with the volume of 30il, but we could not verify lung expansion. There was no difference in BW between ventilated and non-ventilated fetuses of the same group ( $p>0.05)$. The fetuses in group $C$ had higher BW than the ones in groups $\mathrm{N}$ - and CDH ( $p<0.001)$. There was no difference in TLW between ventilated and non-ventilated fetuses of the same group ( $p>0.05$ ). Fetuses in group $C$ had higher TLW than fetuses of groups and N-CDH $(p<0.001)$, and fetuses of

Table 1 - Causes of ventilation failure stratified by group, volume and accident.

\begin{tabular}{|c|c|c|c|c|}
\hline Volume & Cause & Control $(n=38)$ & $N-(n=68)$ & $\mathrm{CDH}(\mathrm{n}=40)$ \\
\hline & & $C(n=38)$ & $N-(n=20)$ & $\mathrm{CDH}(n=15)$ \\
\hline \multirow{5}{*}{$75 \mu l$} & PT & $5.3 \%$ & $5.0 \%$ & $6.7 \%$ \\
\hline & PM & $15.8 \%$ & $5.0 \%$ & $13.3 \%$ \\
\hline & FTC & $2.6 \%$ & $25.0 \%$ & $46.7 \%$ \\
\hline & Total & $23.7 \%$ & $35.0 \%$ & $66.7 \%$ \\
\hline & & & $N-(n=11)$ & $\mathrm{CDH}(\mathrm{n}=7)$ \\
\hline \multirow[t]{5}{*}{$63 \mu \mathrm{l}$} & PT & & $18.2 \%$ & $71.4 \%$ \\
\hline & PM & & $9.1 \%$ & $0.0 \%$ \\
\hline & FCT & & $27.3 \%$ & $14.3 \%$ \\
\hline & Total & & $54.5 \%$ & $85.7 \%$ \\
\hline & & & $N-(n=35)$ & $\mathrm{CDH}(\mathrm{n}=15)$ \\
\hline \multirow[t]{5}{*}{$50 \mu \mathrm{l}$} & PT & & $8.5 \%$ & $13.3 \%$ \\
\hline & PM & & $0.0 \%$ & $0.0 \%$ \\
\hline & FTC & & $28.6 \%$ & $33.3 \%$ \\
\hline & Total & & $37.1 \%$ & $46.7 \%$ \\
\hline & & & $N-(n=2)$ & $\mathrm{CDH}(\mathrm{n}=3)$ \\
\hline \multirow[t]{4}{*}{$30 \mu \mathrm{l}$} & PT & & $0.0 \%$ & $66.6 \%$ \\
\hline & PM & & $0.0 \%$ & $0.0 \%$ \\
\hline & FTC & & $50.0 \%$ & $0.0 \%$ \\
\hline & Total & & $50.0 \%$ & $66.6 \%$ \\
\hline
\end{tabular}

PT: pneumothorax; PM: pneumomediastinum; FTC: failed tracheal catheterization 
the group $\mathrm{N}$ - showed similar results when compared to the $C D H$ group $(p<0.05)$. Results similar to TLW's were found in the analysis of LLW, TLW / BW and LLW / BW (Table 2).

The morphometric analysis showed progressive pulmonary hypoplasia in fetuses from group N. Among those, hypoplasia was more severe in $\mathrm{CDH}$ fetuses. In general, the ventilation for 30 minutes did not change lung morphometry, except for the N- group, where we observed an increase of $\mathrm{Lm}$ and Lmw after pulmonary ventilation. Pulmonary morphometric data are summarized in Figure 2. Figure 3 shows lungs from several groups, where we can observe the different degrees of lung development.

\section{DISCUSSION}

Models of ventilation in fetuses with $\mathrm{CDH}$ are described in larger animals, such as sheep and rabbits. In fetal sheep pressure-controlled, time-cycled ventilators were used and ${ }^{11-13}$. In rabbit fetuses volume-controlled, timecycled ventilators were used, but pressure-limited ${ }^{21,22}$. In these animals there are only surgical models of $\mathrm{CDH}$, with the downside of having a more expensive maintenance, high abortion rate (rabbits) and a longer gestation (sheep), besides the limited availability of markers for biomolecular studies.

In the small animal model with rat fetuses, the only model described was based on another one, standardized for ventilation of premature rabbits ${ }^{23}$, using a sophisticated, pressure-controlled, time-cycled ventilator, modified and connected to a special tube for ventilation of multiple fetuses in parallel, and other equipment for monitoring flow and pressure, confirming that all fetuses were being ventilated. The adaptation for ventilation in fetal rats was described in $1992{ }^{14}$. However, this model was reproduced in only three other studies ${ }^{15-17}$. In none of

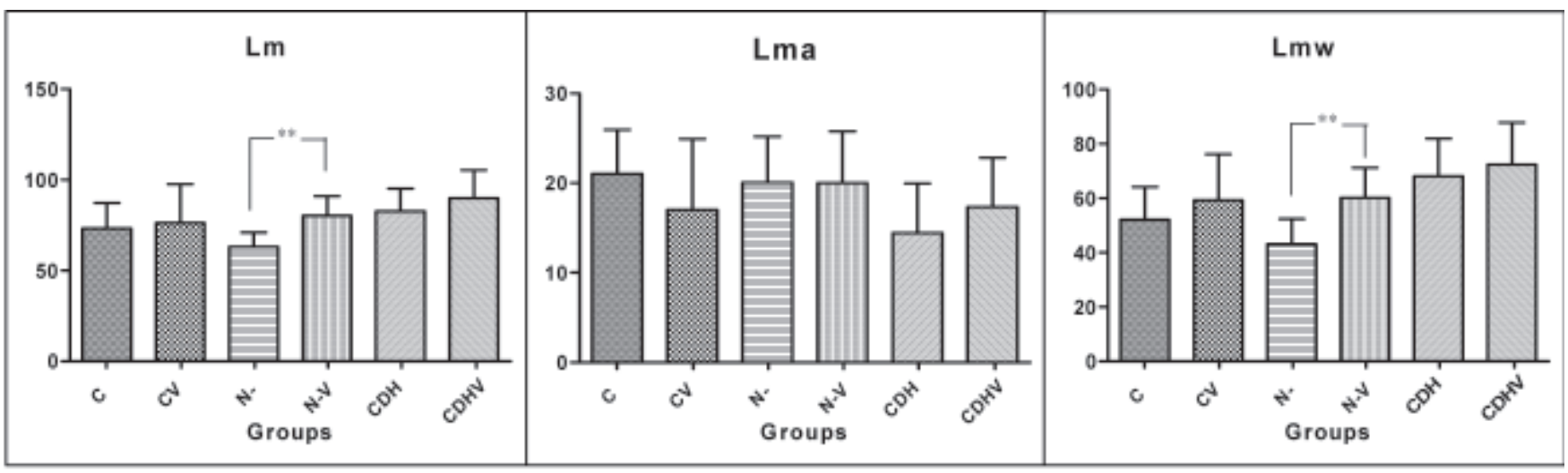

Figure 2 - Morphometric analyzes data between ventilated and non-ventilated groups.

Lm: mean linear intercept, Lma: internal diameter of the airspaces, Lmw: mean wall transection length. ${ }^{\star *} p<0.001$. C: control; CV: ventilated control, $\mathrm{N}$ : exposed to nitrofen; $\mathrm{N}-\mathrm{V}$ : exposed to nitrofen and ventilated; $C D H$ : congenital diaphragmatic hernia; CDHV: congenital diaphragmatic hernia and ventilated. The $y$ axis corresponds to the result of specific calculations for each parameter. C versus CHR - Lmw ( $p$ $<0.001)$ and Lma $(p<0.05)$; $N$-versus CHR: Lm, Lmw ( $p<0.001)$ and Lma $(p<0.05) ; C V$ versus CDHV: $L m$ and Lmw $(p<0.05) ; N-V$ versus CDHV: $\operatorname{Lma}(p<0.05)$.

Table 2 - Fetal morphometric findings (mg) of each ventilated and non-ventilated group.

\begin{tabular}{lccccccc}
\hline & $\mathrm{C}(\mathrm{n}=8)$ & $\mathrm{CV}(\mathrm{n}=8)$ & $\mathrm{N}-(\mathrm{n}=8)$ & $\mathrm{N}-\mathrm{V}(\mathrm{n}=8)$ & $\mathrm{CDH}(\mathrm{n}=8)$ & $\mathrm{CDHV}(\mathrm{n}=8)$ & $p<0.05$ \\
\hline BW & 5640 & 5530 & 4947 & 4683 & 4683 & 4632 & b.c.d.e \\
& $( \pm 223)$ & $( \pm 82)$ & $( \pm 116)$ & $( \pm 87)$ & $( \pm 105)$ & $( \pm 398)$ & \\
TLW & 150 & 139 & 91 & 101 & 75 & 73 & b.c.d.e.g.h \\
& $( \pm 13)$ & $( \pm 9)$ & $( \pm 6)$ & $( \pm 1)$ & $( \pm 1)$ & $( \pm 12)$ & \\
LLW & 50 & 46 & 33 & 37 & 23 & 24 & b.c.d.e.g.h \\
& $( \pm 0.1)$ & $( \pm 0.3)$ & $( \pm 0.5)$ & $( \pm 0.6)$ & $( \pm 3)$ & $( \pm 0.5)$ & \\
TLW / BW & 0.027 & 0.025 & 0.018 & 0.022 & 0.016 & 0.016 & b.c.d.e.g. \\
& $( \pm 0.002)$ & $( \pm 0.002)$ & $( \pm 0.001)$ & $( \pm 0.002)$ & $( \pm 0.002)$ & $( \pm 0.002)$ & \\
LLW / BW & 0.009 & 0.008 & 0.006 & 0.008 & 0.005 & 0.005 & c.d.e.g.h \\
& $( \pm 0.0013)$ & $( \pm 0.0006)$ & $( \pm 0.001)$ & $( \pm 0.001)$ & $( \pm 0.001)$ & $( \pm 0.001)$ &
\end{tabular}

Compared groups - a: C $\times C V ;$ b: $C \times N-; C: C \times C D H ; d: C V \times N-V ; e: C V \times C D H V ; f: N-\times N-V ; g: N-\times C D H ; h: N-V \times C D H V ; i: C D H \times C D H V$. 


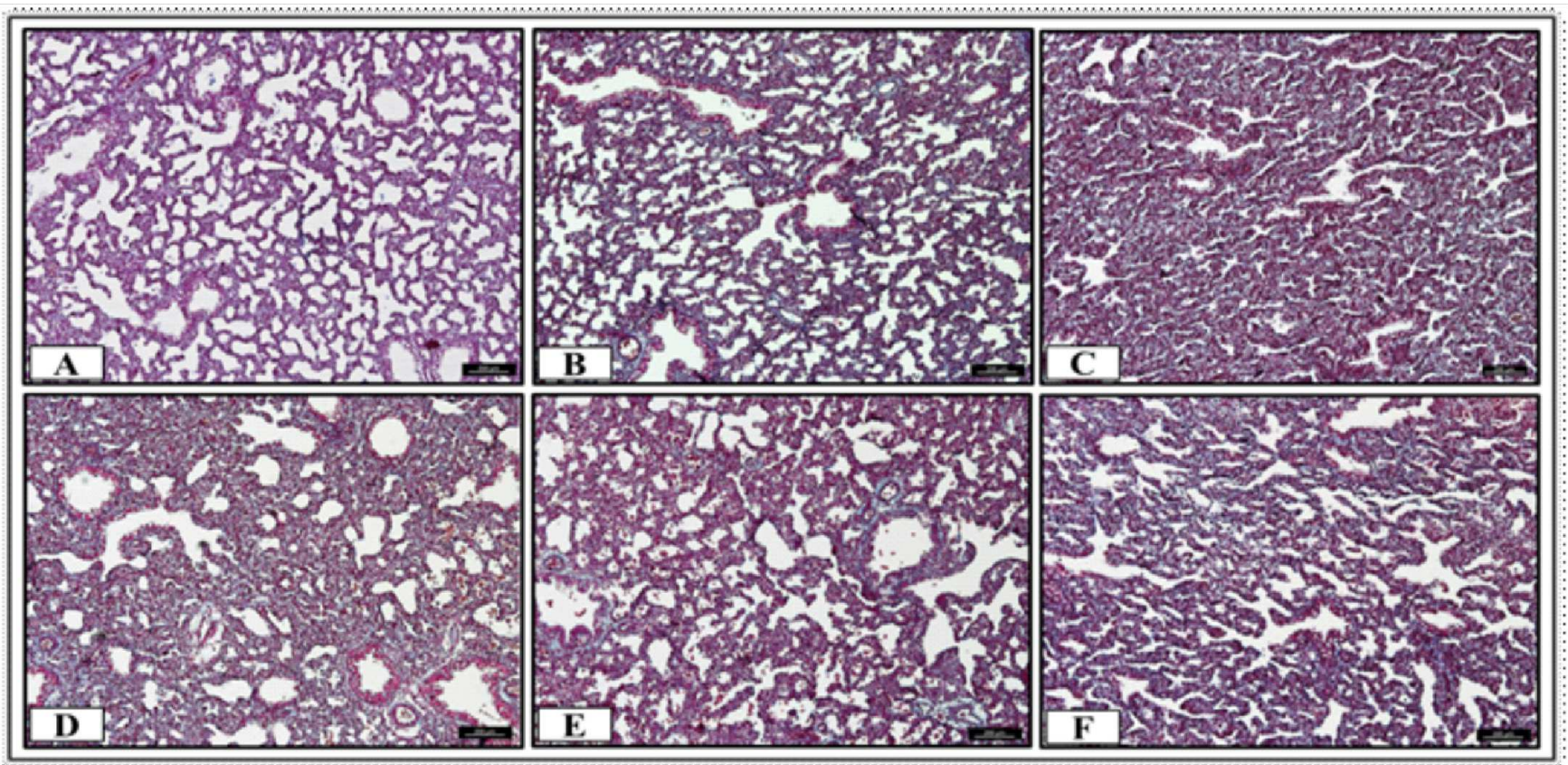

Figure 3 - Aspects of lung development of ventilated and non-ventilated fetuses.

A) control; B) exposed to nitrofen; C) congenital diaphragmatic hernia; D) ventilated control; E) exposed to nitrofen and ventilated; F) congenital diaphragmatic hernia and ventilated. Note in $C$ and $F$ the pulmonary hypoplasia represented by higher density of the parenchyma and scarcity of airspaces, even when ventilated.

these articles, the success rate in tracheal catheterization or complication rate after intubation has been described, since the procedure, the materials used and the fetuses themselves are smaller and of more delicate handling Possibly the lack of description of this maneuver and complications may justify the low reproducibility of the ventilation model in rats. Moreover, in all of them changes in lung molecular biology were noted after a short period of ventilation.

In ventilation model of normal newborn rats, using simpler, volume-controlled, time-cycled ventilators, it may ${ }^{24}$ or may not ${ }^{18,25}$ be pressure-limited. The tidal volume admitted for ventilation ranged from 3.5 to $40 \mathrm{ml} / \mathrm{kg}$, with a volume considered median between 8.5 and $12 \mathrm{ml} / \mathrm{kg}$, and a frequency between 20 and 600 cycles/minute, with the median frequency between 100 and 160 cycles/minute. However, the use of a volume-controlled ventilation in rats can ventilate only the fetus at a time.

We chose to use a slightly higher tidal volume, about $13.5 \mathrm{ml} / \mathrm{kg}$ (75il), but with a lower frequency (80 cycles/min) in fetuses of group $C$ and we had minimum failure rates. We tried to use the same volume for fetuses of group N, however, the rate of complications such as pneumothorax, pneumomediastinum or tracheal catheterization failure were very high, respectively 35 and $66.7 \%$ in $\mathrm{N}$ - fetuses and $\mathrm{CDH}$. We recalculated the volume according to the weight of fetuses exposed to nitrofen, which are smaller (13.5 ml/kg? 63il), but even when ventilating with lower volume, the complication rate still remained high, especially in $\mathrm{CDH}$ fetuses, 54.5 and $85.7 \%$ in fetuses and $\mathrm{N}-\mathrm{CDH}$, respectively. We reduced ventilatory volume $(10.5 \mathrm{ml} / \mathrm{kg}$ and $50 \mathrm{OL})$ and achieved greater success in fetuses with $\mathrm{CDH}$, with a more acceptable complication rate, respectively 37.1 and $46.7 \%$ in fetuses and N-CDH. Finally, we lowered the volume to 30il, and even with properly intubated fetus, visualization of chest expansion with this volume was extremely difficult, so we considered the volume of 50il as the ideal volume for ventilation of the fetuses in the nitrofen group.

As there is a limitation of how to differentiate nitrofen fetuses with and without hernia before sacrifice without a special ultrasound to small animals, we had to use a volume that did not overload the lungs of CDH fetuses, but could also properly expand and ventilate the lungs of the $\mathrm{N}$ - fetuses. Losty et al. evaluated the static lung compliance in fetuses with $\mathrm{CDH}$ and normal rats, and observed a decrease in compliance in the exposed fetuses and, in particular, in fetuses with $\mathrm{CDH}^{26}$, justifying the need for a smaller volume in group $\mathrm{N}$. These results also corroborate the findings of a recent study from our group, which showed lower lung volume and air space in $\mathrm{CDH}$ fetuses ${ }^{27}$.

After the passage of the learning curve, the success rate in ventilation of $C$ fetuses was efficient, whereas in fetuses of group $N$ the learning curve was longer and the success rate of ventilation was lower. Part of this failure can be explained by Xia et al., who reported 
tracheal defects in fetuses exposed to nitrofen with and without $\mathrm{CDH}^{28}$. They observed incomplete rings in 48 and $70 \%$, stenosis 12 and $21 \%$ and vascular rings in 12 and $11 \%$, respectively, in the groups $\mathrm{N}-$ and $\mathrm{CDH}$.

The results of fetal lung morphology and are in agreement with previous studies that observed fetuses of progressively smaller size when exposed to nitrofen ( $\mathrm{N}-$ ) and with $\mathrm{CDH}$, pulmonary hypoplasia in both being higher in $\mathrm{CDH}$ than in $\mathrm{C}$ fetuses ${ }^{14,29,30}$. Ventilation for a short time did not significantly alter this pattern.

Therefore, for the $\mathrm{CDH}$ model in rats, the volume-controlled and timecycled ventilation was feasible, with approximately $50 \%$ of success using the volume of 50 il. Furthermore, the ventilation of short duration (30 minutes) did not change the pattern of the lung parenchyma histology, demonstrating indirect signs of reduced compliance in the lungs of $C D H$ fetuses.

The ventilation of fetal rats with nitrofeninduced $\mathrm{CDH}$ is possible using a volume-controlled, time-cycled ventilator. After the passage of the learning curve, the success rate in ventilation is excellent in $C$ fetuses and reasonable in $\mathrm{N}$ fetuses due to tracheal defects. The ventilation for a short period did not alter fetal or lung morphology.

\title{
R E S U M O
}

\begin{abstract}
Objetivo: padronizar uma técnica para ventilar fetos de rato com HDC usando um ventilador volume-controlado. Métodos: ratas grávidas foram distribuídas em: a) Controle (C); e b) Expostos a Nitrofen com HDC e sem HDC (N-). Fetos dos três grupos foram divididos aleatoriamente em subgrupos ventilados (V) ou não ventilados (NV). Os fetos foram coletados no dia 21,5 da gestação, pesados e ventilados por 30 minutos usando um ventilador volume-controlado. A seguir os pulmóes foram coletados para estudo histológico. Nós avaliamos: peso corporal (PC), peso pulmonar total (PPT), peso do pulmão esquerdo (PPE), razão PPT/PC e PPE/PC, histologia morfológica das vias aéreas e as causas das falhas da ventilação. Resultados: PC, PPT, PPE, LLW, PPT/PC e PPE/PC foram maiores em $C$ em relação a $N-(p<0,05)$ e a $H D C(p<0,05)$, mas não houve diferenças entre os subgrupos $V$ e $N V(p>0,05)$. $A$ morfologia das vias aéreas pulmonares mostrou hipoplasia nos grupos $N$ - e $H D C$, não havendo diferença entre $V$ e $N V(p<0,05)$. Os grupos C e $\mathrm{N}$ - puderam ser ventilados com sucesso usando o volume corrente de 75il, mas a falha de ventilação no grupo HDC só diminuiu quando ventilados com 50il. Conclusão: a ventilação a volume de ratos com HDC por um curto período é possível e não altera a morfologia fetal ou pulmonar.
\end{abstract}

Descritores: Hérnia diafragmática/congênita. Ventilação. Modelos animais. Ratos. Nitrofenóis.

\section{REFERENCES}

1. Rollins MD. Recent advances in the management of congenital diaphragmatic hernia. Curr Opin Pediatr. 2012;24(3):379-85.

2. Veenma DC, de Klein A, Tibboel D. Developmental and genetic aspects of congenital diaphragmatic hernia. Pediatr Pulmonol. 2012;47(6):534-45.

3. van den Hout L, Schaible T, Cohen-Overbeek TE, Hop W, Siemer J, van de Ven K, et al. Actual outcome in infants with congenital diaphragmatic hernia: the role of a standardized postnatal treatment protocol. Fetal Diagn Ther. 2011;29(1):55-63.

4. Harrison MR, Adzick NS, Estes JM, Howell LJ. A prospective study of the outcome for fetuses with diaphragmatic hernia. JAMA. 1994;271(5):382-4.

5. Harrison MR, Langer JC, Adzick NS, Golbus MS, Filly RA, Anderson $\mathrm{RL}$, et al. Correction of congenital diaphragmatic hernia in utero, V. Initial clinical experience. J Pediatr Surg. 1990;25(1):47-55; discussion 6-7.

6. Tonks A, Wyldes M, Somerset DA, Dent K, Abhyankar A, Bagchi I, et al. Congenital malformations of the diaphragm: findings of the West Midlands Congenital Anomaly Register 1995 to 2000. Prenat Diagn. 2004;24(8):596-604.

7. Laberge JM, Flageole $\mathrm{H}$. Fetal tracheal occlusion for the treatment of congenital diaphragmatic hernia. World J Surg. 2007;31(8):1577-86.

8. Wung JT, Sahni R, Moffitt ST, Lipsitz E, Stolar CJ. Congenital diaphragmatic hernia: survival treated with very delayed surgery, spontaneous respiration, and no chest tube. J Pediatr Surg. 1995;30(3):406-9.
9. Wilcox DT, Irish MS, Holm BA, Glick PL. Animal models in congenital diaphragmatic hernia. Clin Perinatol. 1996;23(4):813-22.

10. Kluth $D$, Kangah $R$, Reich $P$, Tenbrinck R, Tibboel D, Lambrecht W. Nitrofen-induced diaphragmatic hernias in rats: an animal model. J Pediatr Surg. 1990;25(8):850-4.

11. Bütter A, Bratu I, Flageole $H$, Laberge JM, Kovacs $L$, Faucher $D$, et al. Fetal tracheal occlusion in lambs with congenital diaphragmatic hernia: role of exogenous surfactant at birth. Pediatr Res. 2005;58(4):689-94.

12. Kapur P, Holm BA, Irish MS, Sokolowski J, Patel A, Glick PL. Lung physiological and metabolic changes in lambs with congenital diaphragmatic hernia after administration of prenatal maternal corticosteroids. J Pediatr Surg. 1999;34(2):354-6.

13. Lewis NA, Holm BA, Swartz D, Sokolowski J, Rossman J, Glick PL. Antenatal vitamin A decreases ventilation-induced lung injury in the lamb model of congenital diaphragmatic hernia. Asian J Surg. 2006;29(3):193-7.

14. Sluiter W, Bos AP, Silveri F, Tenbrinck R, Kraakslee R, Tibboel D, et al. Nitrofen-induced diaphragmatic hernias in rats: pulmonary antioxidant enzyme activities. Pediatr Res. 1992;32(4):394-8.

15. Scheffers EC, IJsselstijn H, Tenbrinck R, Lachmann B, de Jongste JC, Molenaar JC, et al. Evaluation of lung function changes before and after surfactant application during artificial ventilation in newborn rats with congenital diaphragmatic hernia. J Pediatr Surg. 1994;29(6):820-4.

16. Guarino N, Teramoto $H$, Shima H, Oue T, Puri P. Effect of mechanical ventilation on the pulmonary expression and production of elastin in nitrofen-induced diaphragmatic hernia in rats. J Pediatr Surg. 2002;37(9):1253-7. 
17. Shinkai $T$, Shima $H$, Solari V, Puri P. Expression of vasoactive mediators during mechanical ventilation in nitrofen-induced diaphragmatic hernia in rats. Pediatr Surg Int. 2005;21(3):143-7.

18. Kroon AA, Wang J, Kavanagh BP, Kavanagh B, Huang Z, Kuliszewski $M$, et al. Prolonged mechanical ventilation induces cell cycle arrest in newborn rat lung. PLoS One. 2011;6(2):e16910.

19. Dunnill MS. Quantitative methods in the study of pulmonary pathology. Thorax. 1962;17(4):320-8.

20. Verbeken EK, Cauberghs M, Mertens I, Clement J, Lauweryns JM, Van de Woestijne KP. The senile lung. Comparison with normal and emphysematous lungs. 1. Structural aspects. Chest. 1992;101(3):793-9.

21. Flemmer AW, Jani JC, Bergmann F, Muensterer OJ, Gallot D, Hajek $K$, et al. Lung tissue mechanics predict lung hypoplasia in a rabbit model for congenital diaphragmatic hernia. Pediatr Pulmonol. 2007;42(6):505-12.

22. Jani JC, Flemmer AW, Bergmann F, Gallot D, Roubliova $X$, Muensterer OJ, et al. The effect of fetal tracheal occlusion on lung tissue mechanics and tissue composition. Pediatr Pulmonol. 2009:44(2):112-21.

23. Lachmann B, Grossmann G, Freyse J, Robertson B. Lung-thorax compliance in the artificially ventilated premature rabbit neonate in relation to variations in inspiration:expiration ratio. Pediatr Res. 1981;15(5):833-8.

24. Iben SC, Haxhiu MA, Farver CF, Miller MJ, Martin RJ. Short-term mechanical ventilation increases airway reactivity in rat pups. Pediatr Res. 2006;60(2):136-40.

25. Kroon AA, Wang J, Huang Z, Cao L, Kuliszewski M, Post $M$. Inflammatory response to oxygen and endotoxin in newborn rat lung ventilated with low tidal volume. Pediatr Res. 2010;68(1):639.
26. Losty PD, Suen HC, Manganaro TF, Donahoe PK, Schnitzer JJ. Prenatal hormonal therapy improves pulmonary compliance in the nitrofen-induced $\mathrm{CDH}$ rat model. J Pediatr Surg. 1995;30(3):420-6.

27. Sbragia L, Nassr ACC, Gonçalves FL, Schmidt AF, Zuliani CC, Garcia $P V$, et al. VEGF receptors decrease during lung development in congenital diaphragmatic hernia induced by nitrofen. Braz J Med Biol Res. in press.

28. Xia H, Migliazza L, Diez-Pardo JA, Tovar JA. The tracheobronchial tree is abnormal in experimental congenital diaphragmatic hernia. Pediatr Surg Int. 1999;15(3-4):184-7.

29. Tenbrinck R, Tibboel D, Gaillard JL, Kluth D, Bos AP, Lachmann B, et al. Experimentally induced congenital diaphragmatic hernia in rats. J Pediatr Surg. 1990;25(4):426-9.

30. Schmidt AF, Gonçalves FL, Regis AC, Gallindo RM, Sbragia L. Prenatal retinoic acid improves lung vascularization and VEGF expression in CDH rat. Am J Obstet Gynecol. 2012;207(1):76.e2532.

Received on 28/08/2013

Accepted for publication 28/09/2013

Conflict of interest: none.

Source of funding: FAPESP - \# 11/00794-1.

Address for correspondence:

Lourenço Sbragia

E-mail: sbragia@fmrp.usp.br 